5. Luptak M. Social work and end-of-life care: a historical perspective / M.Luptak // Health \& Social Work. 2004. - №29 (1). - P. 7-15.

6. Nacman M. Social work in health settings: A historical review / M. Nacman // Social Work in Health Care. - 1977. - №2 (4). - P. 7-23.

7. Popova, K. Between Public Health and Social Work: Visiting Nurses in the Struggle Against Poverty and Infant Mortality in Bulgaria 1923-1934 / Kristina Popova // Social Work \& Society. - South-West University Blagoevgrad. - Volume 9. - Issue 2. - 2011.- [Electronic resource]. - Mode of access: http://www.socwork.net/sws/article/view/271/599

8. Keefe R. Handbook of Public Health Social Work / R. Keefe, E. Jurkowski. - Edited by the Social Work Section of the American Public Health Association. - Springer Publishing Company, 2013. - 128 p.

9. Lee D. Social work education in the United States: New trends and Issues / D. Lee. - Chicago, IL: Loyola University Chicago, 2008. - 322 p.

10. Kendall K. A. The IASSW 1928-1978: A Journey of Remembrance / K. A. Kendall // Reflections on Social Work Education 1950-1978. - New York: ASSW, 1978. - P. 170-191.

11. Gehlert S. Handbook of Health Social Work / Sarah Gehlert, Teri Browne. - Second edition. - New Jersey: John Wiley \& Sons, Inc. Published by John Wiley\&Sons, Inc., Hoboken. 2012. - 722 p.

12. Cannon I. M. Report on the subcommittee on medical social service / I. M. Cannon (Eds.) // White House Conference on Child Health and Protection. - Hospitals and child care: Section 1. Medical service. - New York, NY: Century, 1932. - P. 131-272.

13. Cabot R. C. Social service and the art of healing / R. C. Cabot. - New York, NY: Moffat, Yard and Company, 1915. $-168 \mathrm{p}$.

14. Grinker R. Early years of psychiatric social work / R.Grinker, H.MacGregor, K.Selan, A.Klein, J.Kohrman // Social Service Review. - 1961. - №35. - P. 111-126.

15. Flexner A. Is social work a profession? / A. Flexner. - Paper presented at the meeting of the National Conference of Charities and Corrections, Baltimore, 1915. MD. URL: http: //socialwelfare.library.vcu.edu/socialwork/is-social-work-a-profession-1915/

16. Dodds T. A. Richard Cabot: Medical reformer during the Progressive Era (1890-1920) / T. A. Dodds // Annals of Internal Medicine. - 1993. - № 119. - P. 417-422.

17. Feustel, A. The story of the foundation of the International Association of Schools of Social Work / A. Feustel. - 2006. - [Electronic resource]. - Mode of access:http://www.iassw-aiets.org. -Accessed: May 2008

18. Stites M. A. History of the American Association of Medical Social Workers. Washington, DC: American Association of Medical Social Workers / Stites, M. A. - 1955. - [Electronic resource]. -Mode of access:http://special.lib.umn.edu/findaid/xml/sw1000.xml

19. California Department of Health Care Services. Mental Health Services Act (MHSA). - 2016. URL:http://www.dhcs.ca.gov/services/mh/Pages/MH_Prop63.aspx

20. Integrated Foundation \& Advanced Competencies For Public Mental Health in California. CalSWEC. 2011, 30 p. - [Electronic resource]. - Mode of access:http://calswec.berkeley. edu/files/uploads/ docx/ Mental\% 2520Health/02_mh_comps_formatted_final.pdf

Отримано редакцією 15.10 .2018 p.

UDK 378

\author{
DOI: 10.31376/2410-0897-2018-3-38-268-274 \\ Dina Demchenko, \\ $\mathrm{PhD}$ in Pedagogy Associate professor of foreign languages \\ chair №2 Yaroslav Mudryi National Law University, \\ (Kharkiv, Ukraine), \\ e-mail: dena.demchenko@gmail.com
}

Tatiana Maleyeva,

Assistant of foreign languages chair №2 Yaroslav Mudryi

National Law University, (Kharkiv, Ukraine),

e-mail: maleyeva2812@gmail.com

\title{
FORMATION OF PROFESSINAL FOREIGN LANGUAGE COMPETENCE OF THE FUTURE LAWYER
}

The article deals with problems of formation of foreign language professional competence of the future lawyer in his/her professional training. Foreign language professional competence includes holistic set of knowledge both in language and in professional sphere, the ability to apply this knowledge in practical professional 
activities. Professional foreign language competence of the representatives of legal profession covers sufficient level of knowledge that would allow them to be understood, to be informed as with all the linguistic aspects of another (foreign) language, and with the professional (legal) vocabulary, peculiarities of professional activities, and the ability to apply knowledge in practice.

Key words: foreign language professional competence, professional sphere, professional (legal) vocabulary, professional activities, mustering of foreign language.

Statement of the problem. Competence (professional, pedagogical, communicative, foreign language, etc.) acquires the status of a special reality, which is essential for both in the field of professional legal education and in the field of practical activity. Since «special forms of competence provide the ability to solve individual tasks in a professional activity» [1, c. 285], it is advisable to refer to the characteristics of the essence of the concept of «foreign language competence of a lawyer» in order to identify and characterize its specification. An analysis of the existing characteristics of the concept of «competence», allows us to reveal the essence of foreign language competence, to characterize its structure.

Analysis of latest research works and publications. The awareness of the necessity to master foreign language as a mean to form foreign language competence is of the top importance in training of future lawyers. Such scholars as Kozakov V., Hutchins, Palmer H., Shadrikov V., Vasilevich V., Saharov N., Pradivlyaniy M. devoted their scientific research to this problem. However, despite a wide range of studies, the relevance of the problem of formation of foreign language professional competence remains the question of time.

Formulation of the purpose of the article. The purpose of the article is to deal with problems of formation of foreign language professional competence of the future lawyer in his/her professional training. Foreign language professional competence includes holistic set of knowledge both in language and in professional sphere, the ability to apply this knowledge in practical professional activities.

Methods. The following theoretical methods of pedagogical research have been used in the article: study of literature, theoretical analyses, and methods of logical generalization. Practical methods like observation, conversation and questioning were also used.

Statement of the basic material. The term «foreign-language» matters when it comes to «another» or a foreign language. A foreign language means language «which is studied outside the conditions of its natural existence, that is, in the educational process, which is not used along with the first one in everyday communication» $[4$, p. 31]. Thus, a foreign language, is in contrast to its native language, is acquired by a person outside the social environment in which this language is a natural means of communication.

Thus, to specificity, the process of forming of foreign competence of a future lawyer in professional training is inextricably linked both to the language in general and to the foreign language directly, since the emergence and existence of a natural language is inextricably linked to the emergence and existence of a person. Language as «a system of language means necessary for communication and transfer of experience from generation to generation» has a social and cultural property. This system exists, first, not only for the individual, but also for the corresponding society.

It should be noted that in legal work, the communicative competence of a lawyer is important, because legal profession belongs to the professions of «huge linguistic responsibility» $[5, \mathrm{p}$. 32], where the word serves as a professional tool, on which depends not only the success of professional activity, but also on the fate of people and society as a whole. Professional competence of a lawyer is connected with communicative competence, which includes knowledge of language means and situations of communication, speech skills, allowing the lawyer to achieve the effectiveness of communication and interaction, to understand different documents, to use adequately language and speech means in specific tasks and conditions of communication.

Since both linguists and psycholinguists view language not only as a certain system of linguistic means, but as one of the aspects of human activity - social (speech activity is mental and creative activity), then the acquisition of a foreign language, aimed at forming in those who are taught, the features of the secondary linguistic personality is conscious (cognitive) and creative process, and not «programmed behavior». Foreign language serves as a source of information about the socio-economic, scientific, technical, and general cultural progress of society, which opens to those who studying it, access to the enormous spiritual wealth of other peoples, and increases the level of their humanitarian education.

The internationalization of social life necessitates mastering and using of foreign language by each individual. It becomes an effective factor in the socio-economic, scientific, technical, and general cultural progress of society, which increases the status of a foreign language as a branch of education.

Gradually the attitude toward mastering a foreign language is gradually changing as a secondary task, which provides only general cultural training of a future specialist, since:

- Foreign language serves as an effective factor in the humanization of education, since its usage is associated with the process of communication aimed at establishing interpersonal relationships. It is considered not 
only as a means of humanization, which influences the development of the personality of the person being taught, but also as part of his professional training;

- It is impossible to express correctly one's opinion in a foreign language without realizing the facts of reality, the objects and phenomena that are being discussed. Consequently, mastering foreign language, its deliberate usage contributes to the development of thinking, mastering foreign language develops logical thinking of the individual, since language reflects logical and systematical awareness of the material world;

- Mastering foreign language in higher educational institutions contributes to developing the students' ability to transfer correctly and competently their thoughts in their native language, prevents and promotes overcoming of professional non-profitability, development of speech culture of the individual;

- Students learn with the help of foreign language: culture, art of the country which language they study, the works of its poets, writers; everyday life, customs, traditions, ethics of the people whose language they study; universal values, etc., and it promotes the develops general culture of a person;

- Mastering foreign language allows you to get acquainted with the culture of a written communication;

- Due to the knowledge of foreign languages, student who has graduated from the Higher educational establishment acquires information about the development of the field of his/her professional activity abroad, has an opportunity to compare the achievements of his/her country with the achievements of colleagues abroad; participate in scientific and technical creativity, ensure the conformity of the results of his/her work to the level of world standards;

- The significance for a future specialist to have different skills in the field of foreign language is determined by the need to read and translate special literature, be able to study and systematize materials about professional activities, to cope with business correspondence in a foreign language, to negotiate dialogue business issues, etc.;

- Gradually, students develop their ability to work freely with professional information in foreign language, which plays an important role in professional activity.

Individual approach in mastering foreign languages, forms the ability of future specialists to acquire necessary knowledge, ability to apply and update it on their own way, process of professional training, in general, is a selection of the most rational and acceptable methods from the existing ones.

According to Nikolayev, any form of using foreign language in a higher educational establishment can be described as follows: the use of a language includes actions performed by individuals (students). Because of these actions, students develop both general and especial communicative language competencies. Formed competencies «are used as needed in different contexts depending on different conditions and different needs for different types of speech activities, which include speech processes and the perception of texts related to specific topics in specific fields».

As the researchers note [2], mastery foreign language by the students of non-language specialties and the use of it has its own specificity both in terms of goals and in terms of choice of methods of work. The leading direction in mastering foreign language is to obtain by those who study, the level of communicative competence that would allow them to use a foreign language in a particular field of professional activity.

The purpose of using foreign language in the process of professional training of future representatives of the legal profession is to help the student to become «able to speak professional foreign language». Under the language capacity of the specialty, scientists understand «the ability of a person who learns to receive relevant information in another language and the ability to communicate in a foreign language», which implies the ability to receive maximum information, using their language tools and creative strategies, unequivocally and competently express their opinions by means of foreign language

However, according to the researchers [2] and their own teaching experience at a higher law school, in practice, there is often a discrepancy between the content of the training of representatives of future legal profession and the main characteristics of the use of a foreign language. Thus, teaching of foreign language is usually separated from teaching students their professional activities using foreign language, and the inclusion in the methodical manuals texts, which contain professional topics can only be considered as an external implementation of the principle of communication between language and vocational training. Acquiring foreign language by law students is limited to the learning of the discipline «Foreign Language», while the opportunities for its use are much wider: in the process of independent and educational work of students, in the process of learning general law and special disciplines, etc. As a consequence, the inability of graduates of higher law schools to be effective, full-fledged professional foreign language communicators is a vivid indication of the ineffectiveness of the use of traditional methods.

In this regard, one of the ways of solving the problem is the question of teaching students foreign language for special purposes or professionally oriented foreign language in order to develop the skills of professional foreign language communication of a modern specialist, «the development of independent work skills that allow the student to replenish knowledge, improve their personal traits, to develop professional skills «, the decision of which is devoted to a number of studies and publications. They consider, in particular, the content of professionally oriented teaching of foreign language at different stages in higher educational institution, identifies new trends in the 
formation of skills of foreign communication, touches upon the socio-cultural aspect, psychological and methodological problems, and proposes methodology for the use of basic materials. Thus, professionally directed teaching of foreign languages in the system of higher educational institutions is considered as a «professionally and pedagogically orientated study taking into account the need for studying foreign language regarding the peculiarities of the future profession and specialty of the future teacher.»

The analysis of the researched problem allows us to assert that general issues, that are related to the formation of the communicative competence of the future specialist for the purpose of professional communication are considered, but the ability of representatives of the legal profession to use foreign language to solve problems of professional activity is not properly provided, in particular at the international level (especially for students of the faculty of international relations). In addition, the process of teaching students foreign language in a higher law school can not be considered the only way of forming his professional foreign language competence, besides, teaching foreign language is not a goal but means of forming the researched phenomenon.

It should be noted, that due to increased interest in foreign languages in modern life, the attention of the scientific community has shifted from the study of the features of literary foreign language to the study of the language used in the real communication of specialists in a particular branch. In this regard, the researchers emphasize that the modern achievements in the field of teaching foreign languages for special purposes reached the following conclusion: since the foreign language finds its application in different situations of communication of professionals of different professions and different specializations within the professional industry, then, having identified the features of typical situations of communication of specialists of each particular branch, it is possible to simulate the process of their real communication, and, having selected the necessary language and linguistic material for this purpose, to narrow down entire wide range of foreign language specialists to the specific needs and thus facilitate language acquisition for special purposes. In our opinion, such a decision contributes to a significant optimization of the process of professional training of future specialists in relation to the acquisition of foreign language and can be used as one of the ways of forming a professional foreign language competence of a representative of the legal profession.

Thus, it can be argued that the main task of mastering foreign language in higher education institutions of a non-formal profile at the present stage is not merely «to teach students to use it as a means of communication in all types of speech activities in a variety of situations» [6, c.241], but to use foreign language in all kinds of professional speech activities, since «the effectiveness of learning depends directly on the degree of approach to the transformation of knowledge, application of skills and abilities to the real conditions».

Since speech activity is carried out in the field of reading, speaking, listening and writing, based on the analysis of the work of scientists and taking into account the conditions and needs of future professional activities of lawyers, it is necessary to note the need to take into account the provisions determined by the scholars:

- the need to improve knowledge of a foreign language (especially English) among students of law institutions (especially students of the faculty of international relations) is constantly increasing as it is in the legal field for direct contacts with foreign counterparts on solving legal problems at the international level, acquired by foreign colleagues, in addition, there is a real possibility of a promising future lawyer, to use in his possession foreign language because of the tendency to create a united European legal field;

- advanced reading (which is, as a rule, the leading speech activity in the process of mastering foreign language in higher education institutions) is considered by the majority of students to be a priority, but at the same time they point out the necessity to develop skills of professionally oriented speech and listening skills for realization of professional functions in direct contacts with foreign colleagues;

- the need for direct written contracts with foreign colleagues and partners, scientists believe that the Bologna process will help countries to create in the future a unified system of law that combines elements of the continental and common law systems, necessitates the development of skills and abilities of writing in foreign language as a type of speech activity, which is conditioned by the necessity of exchanging official information of professional nature in a formalized form (official documents).

Thus, it is quite reasonable to assert that one of the ways of forming the professional foreign language competence of representatives of the legal profession is to train students to read, speak, listen and write foreign language in order to ensure their ability to communicate in their future professional field, that is, to ensure the formation of professional foreign language competence of the future lawyer to orient professionally in foreignlanguage activity, which involves preparing future specialists for business communication in oral and written forms. A prerequisite for achieving this goal is the integrated development of students' skills in all types of speech activities in the process of training. After all, the legal education of the XXI century should be international in content, since globalization significantly influences the change of principles and methods of interstate relations, the formation of a super public legal space. Today, it is required that a graduate of a law school has knowledge of foreign legal sources, their use in practical legal activities, the establishment of relations with foreign colleagues in order to solve common legal problems, use of foreign experience, etc. 
The problem of professional foreign language competence of a future specialist, as «objectively existing, complicated structured phenomenon», the process of its formation was researched by scientists. Thus, in the opinion of the Russian researcher M. Sakharov, the foreign language competence of students is an integrative systemic and value neoplasm of special and foreign language knowledge and skills, value relationships that determine the ability of the individual to manage their activities from the definition of purpose, the choice of means to control and evaluate the results.

Researching foreign-language professional competence of future representatives of the economic field, $\mathrm{V}$. Vasilevich defines this phenomenon as an integrated system of functional components and personal traits; the form of expression of the subject-subject communication of the participants of the interactive-communicative process during the solution of professional tasks. Y. Sukharnikov characterizes the formation of foreign professional competence of future economists as a process, which includes the intermediate didactic-technological stages of this process, namely: forecasting of professionally important qualities of specialists-economists for the production of the future, the formation of the content and design of the program of training of students-economists, designing pedagogical process.

«Second language communicative competence», which provides the competence of a future specialist of the navy, Ukrainian scholar S. Kozakov is defined as «the ability, formed in the process of learning foreign language, to understand and generate appropriate linguistic expressions in accordance with the theoretical positions and methods, freely and adequately to the conditions of socially-role situations of professional activity.» knowledge that performs the informational and communicative function, as well as practical skills and abilities that care for perceptively communicative and interactive communication existing communication functions implemented with the help of foreign language means. «However, we can not, in our opinion, agree that the formation of foreign communication skills is limited only to the process of teaching students foreign language. In the process of professional training of the future specialist, there are much wider opportunities for ensuring the formation of this personal phenomenon: the possibilities of general cultural and professional disciplines, educational and independent work of students, etc.

Expanding the concept of foreign language competence of specialists in technical and economic specialties, M. Pradivlyaniy connects it with communicative language competences and notes the presence in this phenomenon of motivational, moral and ethical and other components aimed at creativity, action and results [6, p.343].

Conclusions. Consequently, on the basis of the analysis of researches of scientists it can be concluded that the foreign language competence of the representative of a certain professional sector is considered as the quality of the personality, which is characterized by the productivity of foreign language activities (that is, speech activity in a foreign language), a high level of creative thinking, which ensures the decoding of foreign language information of a professional character. Foreign language competence includes a holistic set of knowledge in the language and professional spheres, the ability to apply this knowledge in practical professional activities. In addition, foreign language competence involves gaining students the knowledge of culture and the language system they study, which is realized through the formation of language and speech skills in general and vocational vocabulary, which manifests itself in the promotion of independent oral and written expression, and which allows students to understand and take part in communicating with native speakers. So, with regard to the formation of this personal phenomenon we are talking about the need to learn the code, which is known and understandable speakers of the language, regardless of professional activity (language proficiency at the general level), as well as the code of a professional foreign language that is well-known carriers of a foreign language who performs certain professional functions in a particular professional field.

Thus, we can make a general conclusion that foreign-language competence implies professional foreign language qualification of a person. Regarding the professional foreign language competence of the representative of the legal profession, it is imperative to have a sufficient level of knowledge that would allow them to be understood, to be well-informed as with all the linguistic aspects of another (foreign) language, and with the professional (legal) vocabulary, peculiarities of professional activity, availability of sufficient level, the ability to apply knowledge in practice, that is, in practical professional activities, as well as in the field of direct specialization of the representative of the legal profession, that is, in professional activities.

\section{References:}

1. English language for special usage in Ukraine (ESP): project research / British Council in Ukraine; [Astanina N., H.BakaevaG.,Belayeva I.] - K.: Letvit. - 2004. - 124 p.

2. Hutchinson T., Waters A. English for Specific Purposes: a learning-centered approach / T.Hutchinson, A.Waters. - Cambridge University Press, 1987. - 184 p.

3. Palmer H. The Oral Method of Teaching Languages. - Cambridge: Cambridge Univ. Press, 1943. - $87 \mathrm{p}$.

4. Shadrikov V. D. New model of specialist: innovative training and competent approach / V.D. Shadrikov // Hihger education today. - 2004. - № 8. - P.26-31.

5. Pradivlyaniy M.G. Formation of professionally directed foreign competence of technical and economical spesialists by means of modern informative technologies: thieses. cand. dis.: 13.00.04/Mukola Grugogovuch 
Pradivlyaniy; M. Kotzubinskiy Vinnitsa State Ped. University. - Vinnitsa, 2006. -2p.

6 . Vasilevich V.V. Subject-subjective interaction between students and teachers in the process of formation professional foreign language competence of future economists / V.V. Vasilevich //Scientific works: Scientificmethodological magazine. V.42. Ad. 29. Pedagogocal sciences. - Mukolaiv: Ad MDGY, 2005. - P.141 - 147.

\author{
Дина Исхаковна Демченко, \\ доктор философии по педагогике $(\mathrm{PhD})$, \\ доцент, доцент кафедры иностранных языков №2 \\ Национальный юридический університет \\ имени Ярослава Мудрого (Харьков, Украина), \\ e-mail: dena.demchenko@gmail.com \\ Татьяна Евгеньевна Малеева, \\ асистент кафедры иностранных языков №2 \\ Национальный юридический університет \\ имени Ярослава Мудрого (Харьков, Украина), \\ e-mail: maleyeva2812@gmail.com
}

\title{
ФОРМИРОВАНИЕ ПРОФЕССИОНАЛЬНОЙ ИНОЯЗЫЧНОЙ КОМПЕТЕНТНОСТИ БУДУЩИХ ЮРИСТОВ.
}

В статье рассматривается проблема формирования иноязычной профессиональной компетентности будущих юристов в его/ее профессиональной подготовки. Иноязычная профессиональная компетентность включает иелостный набор знаний как в языковой так и в профессиональной сфере, способность применять эти знания в практической профессиональной деятельности. Профессиональная иноязычная компетентность представителей юридической профессии охватывает значительный уровень знаний, который будет способствовать тому, чтобы их понимали, быть проинформированным используя все языковые аспекты другого (иностранного) языка и профессионального (юридического) вокабуляра, особенности профессиональной деятельности, способность применять знания на практике.

Ключевые слова: иноязычная профессиональная компетентность, профессиональная сфера, профессиональной (юридический) вокабуляр, профессиональная деятельность, овладевать иностраннымм языком.

\author{
Діна Ісхаківна Демченко, \\ доктор філософії з педагогіки (PhD), \\ доцент, доцент кафедри іноземних мов №2, \\ Національний юридичний університет \\ імені Ярослава Мудрого (Харків, Україна), \\ e-mail: dena.demchenko@gmail.com \\ Тетяна Євгенівна Малєєва, \\ асистент кафедри іноземних мов №2 \\ Національний юридичний університет \\ імені Ярослава Мудрого (Харків, Україна), \\ e-mail: maleyeva2812@gmail.com
}

\section{ФОРМУВАННЯ ПРОФЕСІЙНОЇ ІНШОМОВНОӤ КОМПЕТЕНТНОСТІ МАЙБУТНЬОГО ЮРИСТА}

Проблема. В статті розглядається проблема формування іншомовної професійної компетентності майбутніх юристів в його/їі професійній підготовиі.

Метою статті є підтвердити, що іншомовна компетентність включає иілісний набір знань як у мовній так і у професійній сфері, здатність застосовувати иі знання в практичній професійній діяльності.

Методи дослідження. У статті використані наступні теоретичні методи педагогічного дослідження: вивчення літератури, теоретичний аналіз,методи логічного узагальнення, а також використані практичні методи: спостереження, розмова та допит.

Основні результати дослідження. Професійна іншомовні компетентність представників юридичної професії охоплює значний рівень знань, який буде сприяти тому, щэоб їх розуміли, всі мові аспекти другої (іншомовної) мови та професійного (юридичного) вокабуляра, особливості професійної діяльності, здатність застосовувати знання на практиці.

Наукова новизна статті полягає у тому, що найважливішою якістю сучасного фахівия є його 
здатність до ефективної повноцінної професійної іншомовної комунікації.

Висновки та конкретні пропозиції. Специфіка процесу формування іншомовної компетентності майбутнього юриста у фаховій підготовиі невід 'ємно пов'язана як з мовою взагалі, так із іноземною мовою безпосередньо. Використання іноземної мови в проиесі підготовки майбутніх представників юридичної професії полягає в тому, щоб допомогти студентові стати «дієздатним з іноземної мови за фахом».

Ключові слова: іншомовна професійна компетентність, професійна сфера, професійній (юридичний) вокабуляр, професійна діяльність, оволодіння іноземною мовою.

\section{Список використаних джерел та літератури}

1. Англійська мова спеціального вжитку в Україні (ESP): допроектне дослідження / Британська Рада в Україні; [Астаніна Н., Бакаєва Г., Бєляєва І.] - К.: Ленвіт. - 2004. - 124 с.

2. Hutchinson T., Waters A. English for Specific Purposes: a learning-centred approach / T.Hutchinson, A.Waters. - Cambridge University Press, 1987. - 184 p.

3. Palmer H. The Oral Method of Teaching Languages. - Cambridge: Cambridge Univ. Press, 1943. - 87 p.

4. Шадриков В.Д. Новая модель специалиста: инновационная подготовка и компетентностный подход / В.Д.Шадриков // Высшее образование сегодня. - 2004. - № 8. - С.26-31.

5. Прадівлянний М.Г. Формування професійно спрямованої іншомовної компетентності фахівців технічних та економічних спеціальностей засобами сучасних інформаційних технологій: автореф. канд. дис.: 13.00.04/ Микола Григорович Прадівляний; Вінницький держ.пед.ун-т ім.. М.Коцюбинського. - Вінниця, 2006. $-20 \mathrm{c}$.

6. Василевич В.В. Суб'єкт - суб’єктна взаємодія викладачів і студентів у процесі формування іншомовної професійної компетентності майбутніх економістів / В.В. Василевич // Наукові праці: Науковометодичний журнал. Т.42. Вип. 29. Педагогічні науки. - Миколаїв: Вид-во МДГУ ім. П.Могили, 2005. C.141-147.

Отримано редакцією 25.09 .2018 p.

\section{УДК 374.091:[338.48:908]-053.5(477.52)’'195/198”， DOI: 10.31376/2410-0897-2018-3-38-274-280 Ірина Володимирівна Пархоменко, аспірантка Сумського державного педагогічного університету імені А.С.Макаренка, e-mail: parkhomenkoiv@ukr.net \\ РОЗВИТОК ЗАКЛАДІВ ПОЗАШКІЛЬНОЇ ОСВІТИ ТУРИСТСЬКО-КРАЕЗНАВЧОГО НАПРЯМУ СУМСЬКОЇ ОБЛАСТІ (50-80-ті роки XX століття)}

У статті подано особливості розвитку закладів позашкільної освіти туристсько-краєзнавчого напряму УРСР на прикладі Сумської обласної дитячої екскурсійно-туристської станції (Сумської обласної станиії юних туристів) у 50-80-их роках ХХ століття. Автор пропонує періодизацію зародження та розвитку системи закладів позашкільної освіти туристсько-краєзнавчого напряму в Украӥні, зокрема в Сумській області. Наукова новизна результатів дослідження полягає у представленні архівних матеріалів щчодо діяльності Сумської обласної дитячої екскурсійно-туристської станиії (Сумської обласної станиї юних туристів).

Ключові слова: заклади позашкільної освіти туристсько-краєзнавчого напряму, станиія юних туристів, дитяча екскурсійно-туристська станція, туристсько-краєзнавча робота, Сумська область.

Постановка проблеми. Дослідження розвитку закладів позашкільної освіти туристськокраєзнавчого напряму сьогодні є особливо актуальним, оскільки саме цей напрям позашкільної освіти має наскрізний національно-патріотичний вектор, дає змогу в юному віці пізнати не лише свою країну, а першочергово досліджувати історію та культурний розвиток рідного краю. 3 огляду на це науковий супровід вибраної тематики є своєчасним і потрібним.

Водночас, на нашу думку, розвиток дитячого туристично-краєзнавчого руху, що мав місце у 50-80-их pp. ХХ століття на території Сумської області є недостатньо вивченим, особливо це стосується засадничих аспектів історико-краєзнавчої роботи, що унеможливлює використання позитивних здобутків або врахування недоліків у сучасних умовах.

Аналіз останніх досліджень і публікацій. Початки наукового дослідження системи позашкільної освіти закладені у радянській історіографії, і свідченням цього $є$ не лише окремі збірники, документи чи періодичні видання того періоду, а й дисертації. 